Our research indicates that there is a range of rationales for international faculty recruitment and a wide array of ways in which foreign academics are recruited. Terms of employment can also differ-they may be identical to those offered to domestic faculty, or unique for internationals, with either scenario potentially resulting in challenges and opportunities for all involved. Further, the manner and extent to which the presence of foreign faculty exerts an impact on their host institutions seems rarely explored, documented, or leveraged systematically.

Finally, the story of international faculty mobility is not complete without a consideration of what this phenomenon means at the most fundamental level — that of the individual academic. Here, our research shows that mobile faculty are often motivated by attractive employment opportunities or a sense of duty or desire to contribute to a "larger agenda" that they believe in. They are sensitive to the personal supports that the host institution or country can provide. The universities examined in our study, however, vary widely in terms of systematic provision of such supports.

\section{What We Do Not Know}

There is much to explore and yet to understand about the international faculty mobility phenomenon. Some of the key issues we see on the horizon for future research include the way immigration/migration policies affect international faculty mobility; international faculty mobility in developed versus emerging societies, in the public higher education sector versus the private and for-profit sectors, and across disciplines, age, and gender; the impact of online education on international faculty mobility; and the differences in the realities of faculty mobility across various institutional types.

\section{Brexit: Challenges for Universities in Hard Times}

\section{SimON MARGINSON}

Simon Marginson is professor of International Higher Education, Institute of Education, University College London, and director, ESRC/HEFCE Centre for Global Higher Education, UK. E-mail: s.marginson@ ucl.ac.uk.

$\mathrm{W}$ ith the referendum of 23 June 2016 , in which 72 percent of the electorate voted (highest turnout since I992), the British voted to take their country out of the European Union by a margin of 52/48 percent. Though it was unclear in the early weeks what "Brexit" meant, even whether the United Kingdom would leave the European Union at all, the post-Brexit landscape is now emerging. In the House of Commons, in March 20I7, Prime Minister Theresa May will table the complex bill to leave the European Union.

For higher education, one UK sector where the relationship with Europe has been unambiguously positive-a win-win for both European countries and the United Kingdom-the consequences will be every bit as destabilizing as was predicted before the vote.

\section{Blockages to People Mobility}

The government of Theresa May has made it clear the era of free people movement between the United Kingdom and the European Union is over. Above all, it was migration resistance that determined the referendum result. There will be a new migration program, in which people of all origins will be treated on a common basis, favoring high-skill migration. In addition, May wants a significant reduction in the overall level of migration into the United Kingdom. The prime minister sees both measures as essential to the political survival of the Conservative Party government.

What happens to EU citizens in UK universities is unclear. Currently there are 43,000 EU staff and I25,000 EU students. However, the Brexit process cannot be completed before March 20I9, by which time most current students will be through their courses. While EU staff are likely to retain residence rights, this is still uncertain, as no announcement has been made. Their position may depend on whether reciprocal rights of residence are negotiated successfully for UK citizens presently resident in Europe.

The decision to give priority to closing down EU people movement has momentous consequences, signaling a "hard Brexit" in which the United Kingdom loses access to the single market in Europe. Even partial economic participation in Europe, as in Switzerland and Norway, depends on support for free people movement. A "hard Brexit" directly undermines the UK finance sector in the City of London, the strongest British industry and one of two domains where the United Kingdom is a clear global leader. The other is higher education.

UK-based finance will lose the special "passport" that enables foreign banks and other companies operating in London to access the European market without needing separate licenses for each country. On I8 September, the president of Germany's central bank, the Bundesbank, predicted that many financial services will relocate to Frankfurt. In addition, London will lose its role as a principal trader in euros. The Japanese government has stated it will relocate its banks if the "passport" is lost. Hitachi, Honda, Nissan, and Toyota have large plants in the United Kingdom as their base for accessing Europe. They may also have 
to relocate.

In order to reduce net migration quickly, the government is considering a large cut in fee-paying international student numbers - 30 percent has been floated. Almost one in five of all students in United Kingdom are international. They are classified as temporary migrants. The reduction would be partly achieved by requiring EU students to pay the same fees as non-EU students. Currently, non-EU students pay much higher tuition fees than first degree EU students, who access the same income contingent loans scheme as domestic UK students. It is unlikely that the same number of EU students will continue to flow from, say, Denmark, the Netherlands, and Germany, given that they have excellent universities in their own countries and in the United Kingdom would have to pay $£_{12}, 000-20,000$ a year in up-front fees.

\section{For higher education, one UK sector where the relationship with Europe has been unambiguously positive-a win- win for both European countries and the United Kingdom-the consequenc- es will be every bit as destabilizing as was predicted before the vote.}

In addition, a large cut in international students would also affect non-EU international students. Before the last election, Theresa May, then Home Secretary in charge of immigration policy, stated that universities in the United Kingdom should develop new business models with less dependence on revenue from international education. The Home Office will support any cut in numbers by claiming there are high rates of overstay, making a bogey out of international students, though its overstay data are murky.

International students currently supply an estimated fI7.5 billion to the UK economy. Any reduction of international student numbers and revenues will be felt most harshly by universities positioned lower down in the status order of higher education, and in the local businesses and provincial cities and towns that service international education.

For international education in the United Kingdom, the only positive is that in the longer term a migration regime prioritizing high skills will encourage graduates to stay on by liberalizing the highly restrictive graduate visa regime. Currently, graduates must be in a job earning at least $£ 35,000$ per year, the median wage in skilled UK jobs, to secure a work visa.

\section{Reduced Research Collaboration}

It is highly unlikely that UK universities will retain membership of the mainstream European research programs, though there may be continued limited access in some areas. The net effect of retarding people movement and taking the United Kingdom out of combined research teams will be to reduce the flows of knowledge, and weaken both UK and European research. Currently, more than half of all doctoral students in the United Kingdom are foreign born.

Some UK universities, possibly with government support, will make strenuous efforts to build bilateral and university-to-university infrastructure in place of the European research area. Yet bilateral infrastructures are both more expensive overall and unable to deliver the scale of European schemes. Research in Europe taken together matches research in North America. Research in the United Kingdom and one other country does not.

UK universities currently receive $£^{\mathrm{I}}$ billion a year through European programs such as Horizon 2020 and the European Institute of Innovation and Technology. The United Kingdom spends only 0.44 percent of its GDP on research in higher education, well below investments in Northwestern Europe, and I9.7 percent of all UK R\&D money is sourced from outside the country, mostly through European funding schemes. This is Europe's second highest level of dependence on international revenues, after Ireland. Any reduction in research resources is likely to be felt especially harshly in leading and middle-level universities. It will trigger increased UK collaboration with the fast-rising research systems of China and East Asia.

Some in UK government are worried about the effects of Brexit in science. Here higher education has its best prospects of compensation. While the international education sector has long called for students to be taken out of the migration target, this now looks unlikely. Cutting international students is disruptive and costly, but much the easiest way to cut total migration-and the government is scarcely likely to exempt the universities from Brexit while it overrides a much more powerful constituency in the City of London.

"Hard Brexit," accumulating migration resistance elsewhere in Europe, and the Trump victory in the United States, signal a new era of politics in which, on a bad day, national security and identity, and deliberate blockages to mobility, can overdetermine global openness, trade, economic enrichment, and the global knowledge society we are building in higher education.

Conflicts in the Middle East from Libya to Afghanistan, the growing US/China tension and the potential flashpoints on the borders encircling China, also suggest a world in 
which national security and military goals loom larger than learning, discovery, and even capital accumulation. Higher education is just one part of the collateral damage. We have chafed under the rule of economic objectives in higher education. We now have a larger problem.

This means that, more than ever, universities have a vital role to play in working across borders, in sharing each other's spaces, in building collaboration and understanding, and in applying dispassionate human intelligence to solving the many problems before us. Brexit makes it harder, but will not stop UK and European universities from working together.

\section{What is the Teaching Excellence Framework in the United Kingdom, and Will it Work?}

\section{Paul Ashwin}

Paul Ashwin is professor of higher education, Department of Educational Research, Lancaster University, and a researcher in the ESRCHECFE funded Centre for Global Higher Education, UK. E-mail: p.ashwin@lancaster.ac.uk. For further information on the TEF see: http://www.hefce.ac.uk/lt/tef/ and https://www.gov.uk/government/ collections/teaching-excellence-framework.

Tn England, the government has begun the introduction 1 of a new Teaching Excellence Framework (TEF) in higher education. Since tuition fees for UK and EU students were increased to a maximum of $£ 9000$ from the autumn of 20I2, most English higher education providers have ended up charging this maximum. There is a sense in government that these flat fees mask differences in the quality of degree programs that students are being offered. One of the central ideas behind the TEF is that in order for institutions to raise fees in line with inflation, they will need to show that they are offering students a high quality undergraduate education. This will mean that the fees that students are charged will increasingly reflect the quality of the teaching they experience. In addition, it is expected that the TEF will provide students with information that will allow them to make more informed choices about what and where they study; will raise the profile of teaching and ensure that it is better recognized and rewarded; and will lead to higher education better meeting the needs of employers and in- dustry.

\section{HOW WILL THE TEF WORK?}

The TEF will be introduced over a number of years. In year I, any institution with a positive Quality Assurance Agency Institutional Review is automatically qualified to increase its tuition fees from September 20I7. From year 2, institutions will need to opt into the TEF, which will examine a series of metrics: students' views of teaching; assessment and academic support from the National Student Survey (NSS); student dropout rates; rates of employment, including a measure of highly skilled employment; and further study from the Destinations of Leavers from Higher Education (DHLE) survey. While the NSS does give an insight into students' perceptions of their teaching, it is notable that none of these measures tell us directly about the quality of teaching. Rather, these measures are focused on examining the assumed effects of such teaching. Institutions performance will be benchmarked against the demographic characteristics of their students, and based on this, their performance will be flagged when they do statistically significantly better or worse than their benchmark.

Assessors will make an initial assessment of an institution's performance based on the amount of flags they have and then will examine contextual information and an institutional submission of up to I5 pages that outlines the institution's case for the excellence of its teaching. Based on this, they will give the institution a Gold, Silver, or Bronze TEF award. This will provide students with an indicator of the quality of the programs offered by these institutions as whole, rather than the quality of individual programs. In year 2, institutions with each of these awards will be able to raise their fees by the same amount in September 2018 . In year 3, the different level of awards will begin to impact on the amount by which institutions can raise fees in September 20I9, and there will also be pilots aimed at focusing the TEF down onto individual subjects within institutions. In year 4 , it is planned that the subject level TEF will be introduced, and the TEF will also include taught postgraduate students.

\section{Will the Tef Meet its Aims?}

In some ways, the TEF will provide students with better information about the quality of their degree programs than what is currently offered by national higher education rankings. While they do not directly tell us about the quality of teaching, there is a logic to the metrics suggested for year 2: it is difficult to imagine an excellent course in which the students think the teaching, support, and assessment are poor; a large proportion of the students leave without graduating; and hardly anyone gets a job or a place on a postgraduate course at the end of it. The commitment to 